\title{
Influence of spot mounding on height growth and tending of Norway spruce: case study in Latvia
}

\author{
Baiba Dzerina, Sigitas Girdziusas, Dagnija Lazdina, \\ Andis Lazdins, Jurǵis Jansons, Una Neimane and \\ Äris Jansons*
}

\begin{abstract}
Dzerina, B., Girdziusas, S., Lazdina, D., Lazdins, A., Jansons, J., Neimane, U., Jansons, Ā. 2016. Influence of spot mounding on height growth and tending of Norway spruce: case study in Latvia. - Forestry Studies | Metsanduslikud Uurimused 65, 24-33. ISSN 1406-9954. Journal homepage: http:// mi.emu.ee/forestry.studies
\end{abstract}

\begin{abstract}
Norway spruce is commonly regenerated by planting and disc trenching is by far the most widely used soil preparation method in Latvia; however, in specific site conditions other methods might be beneficial. Therefore aim of our study was to assess influence of spot mounding on early growth and tending of Norway spruce in hemiboreal forests. Spot mounding was compared with disc trenching or no soil preparation in central part of Latvia $\left(57^{\circ} \mathrm{N} 24^{\circ} \mathrm{E}\right)$ in five different forest types, where two-year-old containerized Norway spruce seedlings were planted. Influence of soil preparation method on tending was assessed in the same region in two different sites in a single forest type on drained fertile mineral soil. Spot mounding had positive effect on the height increment of the dominant trees at the $6^{\text {th }}$ to $8^{\text {th }}$ growing season. Mean height of Norway spruce at the end of $8^{\text {th }}$ growing season on mounds significantly exceeded that on unprepared soil: $179 \pm 6.5$ and $152 \pm 6.2 \mathrm{~cm}$, respectively. Similarly mean height on mounds was significantly larger than on furrows: $209 \pm 3.9$ and $154 \pm$ $4.0 \mathrm{~cm}$, respectively. Projective vegetation cover before the tending was significantly higher in spot-mounded, but after - in disc trenched sites. Networking time for brashsaw operators in spot-mounded $\left(478 \mathrm{~min} / \mathrm{ha}^{-1}\right)$ and disc trenched $\left(462 \mathrm{~min} / \mathrm{ha}^{-1}\right)$ sites was similar $(p>0.05)$. Overall, spot mounding ensured more suitable microenvironment resulting in higher productivity of planted trees and had no negative effect on quality or efficiency of tending, therefore its wider use is recommended.
\end{abstract}

Key words: soil preparation method, height increment, weed control, Picea abies.

Authors' address: Latvian State Forest Research Institute "Silava", 111 Rigas st., Salaspils, LV2169, Latvia; *e-mail: aris.jansons@silava.lv

\section{Introduction}

Norway spruce (Picea abies (L.) Karst.) occupies significant forest areas and is one of the most cultivated tree species in Baltic Sea region countries. For example, in Latvia, based on data from National Forest Inventory, its stands cover $17 \%$ from the total forest area and, according to data of State Forest Service, in 2015 altogether 6531 ha was regenerated with this tree species. Natural regeneration of coniferous DOI: 10.1515/fsmu-2016-0009

(C) 2016 Estonian University of Life Sciences. All rights reserved trees in hemiboreal forests on fertile soils after the clear-cut is very unlikely and/or time consuming. It has been demonstrated already in middle of previous century, when large-scale inventory found, that more than $70 \%$ of the clear-cuts in coniferous forests in such site conditions naturally regenerate with broadleaved trees (Sarma, 1959). Also studies indicate that planted spruce stands have considerably higher productivity than naturally regenerated ones (Gradeckas \& Malinauskas, 2005). It is achieved partly 
due to realization of tree breeding results (Jansons et al., 2015) and partly due to positive influence of soil preparation (Nordborg et al., 2003; Heiskanen et al., 2013).

Various soil preparation methods, like ploughing, disc trenching, soil inversion, mounding (Mangalis, 2004; Gradeckas \& Malinauskas, 2005) can be applied; however in Baltic States by far most commonly used is disc trenching. Conditions created by disc trenching or ploughing are not always optimal for the seedlings. For example, Örlander et al. $(1990,1998)$ have found that survival of trees planted on furrows is similar to that of trees planted on mounds in sites with normal moisture regime, but notably and significantly lower in wet sites. Also other studies have concluded that mounds creates favourable moisture regime that is essential for early survival of Norway spruce (Schlyter et al., 2006). Planting on mounds improves not only the survival, but also initial growth of the trees (Nordborg et al., 2003; Hallsby \& Örlander, 2013; Heiskanen et al., 2013). Young trees on mounds are less likely to be affected by frosts (Langvall et al., 2001; Heiskanen et al., 2013) and better protected from pine weevils (Örlander et al., 1990; Heiskanen \& Viiri, 2005; Saksa, 2008; Heiskanen et al., 2013) that tend to avoid rather large open soil area around the seedling (Wallertz, 2009). Furthermore, mound excluded competition from surrounding vegetation for a longer period of time than furrows (Lehtosalo et al., 2010). For example, in Finland it was found, that in sites where spot mounding was applied, tending was needed only in $2^{\text {nd }}-4^{\text {th }}$ year after planting in relative fertile soil, and in $4^{\text {th }}-6^{\text {th }}$ year in poor soil (Saksa, 2008; Uotila et al., 2010). Therefore, some authors (Uotila et al., 2010) suggest that financial assessment of forest regeneration shall include not only planting (and survival of planted trees), but also tending: its frequency (number of occasion), quality and time spent (costs). Time spent for soil preparation (and thus also the costs and potential for their reduction) had been analysed in numerous studies (Rantala et al.,
2010; Liepiņš et al., 2011). However, there is still very limited information on time spent for tending in the context of soil preparation method in Baltic States.

Most of above mentioned studies had been carried out in boreal forest with different climatic conditions and soil fertility (important both for tree as well as ground vegetation growth) than in hemiboreal forests. Therefore, the aim of our study was to estimate influence of spot mounding on early growth and tending of Norway spruce in hemiboreal forests.

We hypothesised that spot mounding has significant positive influence on tree height increment in comparison to disc trenching or no soil preparation. Larger tree height consequently would ensure faster tending in sites prepared by spot mounding (though trees are not planted in rows) than in sites prepared by disc trenching.

\section{Material and Methods}

Evaluation of influence of spot mounding on growth of Norway spruce was based on trials from central part of Latvia $\left(57^{\circ} 36^{\prime} \mathrm{N}\right.$ $\left.24^{\circ} 36^{\prime} \mathrm{E}\right)$, located in middle of hemiboreal forest zone (Barbati et al., 2007). Data on tree height were collected in Norway spruce stands established in two clear-cut areas (sites), two replications per site. In autumn of 2008 in one of the sites spot mounding and disc trenching was applied, while in other site spot mounding and no soil preparation was done. In study sites in total 5 different forest types (classified according to Bušs, 1976): Myrtillosa, Hylocomiosa, Oxalidosa (mineral soil, normal moisture regime, arranged according to increasing soil fertility), Myrtillosa turf. mel. (peat soil, drained, fertile), Myrtilloso-polytrichosa (mineral soil, wet, fertile), were represented.

Planting was carried out immediately after soil preparation (in autumn) using two year old containerized Norway spruce seedlings with similar size in each of the sites and treatments: height ranged from 16 
to $36 \mathrm{~cm}$ (average $23 \pm 0.5 \mathrm{~cm}$ ), root collar diameter: from 1.5 to $4.5 \mathrm{~mm}$. Planting material in both sites was from the same provenance region (category: selected), grown in the same nursery. After planting in both sites regular treatment according Latvian forestry practice was applied, i.e. clearing from competing vegetation during first 4 growing seasons.

In winter of 2014/2015 height of all Norway spruce trees as well as last three years annual height increment was measured with the accuracy of $1 \mathrm{~cm}$. Also defects (broken tops, spike knots) were evaluated and recorded, however frequency of trees with them was low $(<2 \%)$ and no specific tendencies in relation to soil preparation method or site were detected. As this study focuses on the height of vital trees, data of damaged trees were excluded from further analysis.

Tending time and quality was evaluated in Myrtillosa mel. forest type (mineral soil, drained, fertile), since it is characterized by fast growth and high density of competing ground vegetation, representing the most challenging conditions for this work. Also for this part of the study two clear-cut areas (sites) were used. In each of the sites spot mounding and disc trenching (two replications per site) was applied before the planting. Similar containerized seedlings than in the first part of the study were planted and, at the time of tending (end of first vegetation season after planting), had reached mean height of $28 \pm 0.7 \mathrm{~cm}$.

In each parcel (defined by replication and site) four blocks of 0.25 or 0.5 ha (depending on size of the parcel) were systematically placed. On the longest diagonal of the blocks 10 circular plots $\left(r=2.82 \mathrm{~m}\right.$, area $\left.25 \mathrm{~m}^{2}\right)$ were systematically (even distances between the centres) marked out. In each of these plots assessment of ground vegetation (projective area) was carried out before and after the tending based on ICP Forest method (ICP Forest, 2011), distinguishing five groups of plants (shrubs, sprouts, half-shrubs, grasses, other ground vegetation). Also area of bare soil in each plot, created in process of soil preparation, was measured. Inventory was carried out by a single person to ensure comparability of the estimates. Mean height of each vegetation group was measured in each plot (accuracy $0.1 \mathrm{~m}$ ). Tending was carried out by 5 brush saw operators (the same persons working in areas where spot mounding and disc trenching was used) in the end of August. Networking time (period when the brush-saw was operated) as well as total working time of the operators in each of the blocks was recorded (accuracy $0.1 \mathrm{~min})$.

Data analysis was carried out in SPSS applying ANOVA and $\chi^{2}$ test. To characterise the variance, $95 \%$ confidence interval was used. One-way analysis of variance and Tukey's HSD test was used to assess the differences of tree height (and height increments) between particular forest types and soil preparation methods. To evaluate the impact of soil preparation method, forest type, and interaction of both factors, two-way analysis of variance was used. Impact of the soil preparation method on height growth of trees was also characterised using dominant trees: highest, corresponding to density 100 trees ha-1 (Donis, 2014).

The relation between tree height and soil preparation method was also evaluated comparing distribution of trees in different height classes $(h>2.5 \mathrm{~m} ; 2<h \leq 2.5 \mathrm{~m}$; $1.5<h \leq 2 \mathrm{~m} ; h \leq 1.5 \mathrm{~m}$ ), in each of forest type separately; $\chi^{2}$ test was use to assess the differences of distribution. The differences of projective cover and height of competing vegetation before and after tending, as well as the differences of the networking time (and its proportion from total working time) for sites with different soil preparation were assessed by one-way analysis of variance and Tukey's HSD test. 


\section{Results and Discussion}

Growth of Norway spruce in relation to soil preparation method

The forest type $(p<0.001)$, soil preparation method $(p<0.001)$ as well as interaction of both factors $(p<0.001)$ had significant effect on the height of trees at age of 8 years; however statistically significant influence of replication was not detected $(p>0.05)$.

Regardless of soil preparation method, the highest $(198 \pm 3.8 \mathrm{~cm})$ mean tree height was found on Oxalidosa forest type. Similarly, largest mean height of Norway spruce seedlings at the same age had been found in Oxalidosa forest type also in Lithuania (Gradeckas \& Malinauskas, 2005), conforming the suitability of this forest type for establishment of productive spruce stands.

Mean tree height on mounds notably and significantly exceeded that on unprepared soil (height difference $27 \mathrm{~cm}$, corresponding to $17.8 \%$ ) or furrows $(55 \mathrm{~cm}, 35.7 \%)$. Similar results were obtained also in analysis of the distribution of trees in different height classes: the proportion of highest trees was significantly higher in spot-mounded sites (Figure 1).

Consequently, mean height of dominant trees in spot-mounded sites exceeded that on disc-trenched ones significantly $(p<0.05)$ in all forest types (Figure 2).

Detailed analysis demonstrated that differences in tree height distribution between soil preparation methods were significant in Myrtillosa, Oxalidosa and Myrtillosopolytrichosa forest types. Similar trend was noted in Hylocomiosa and in Myrtillosa turf. $m e l$. forest types, however, these differences were non-significant $(p=0.05$ and $p=0.53$, respectively). Differences were more pronounced, when trees growing on mounds were compared with those growing in unprepared soil: in these circumstances one

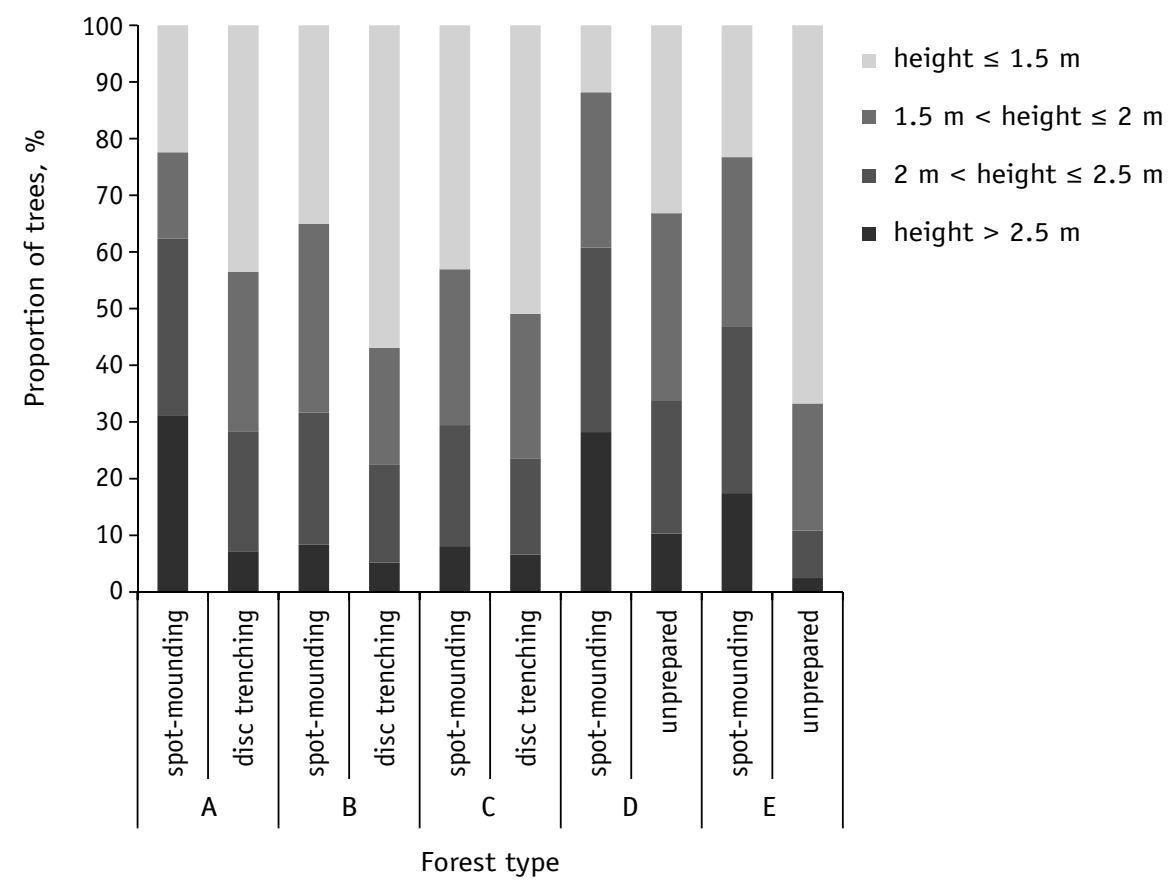

Figure 1. Distribution of trees in height groups at the age of 8 years in different forest types: Myrtillosa (A), Hylocomiosa (B), Myrtillosa turf. mel. (C), Oxalidosa (D), Myrtilloso-polytrichosa (E). 


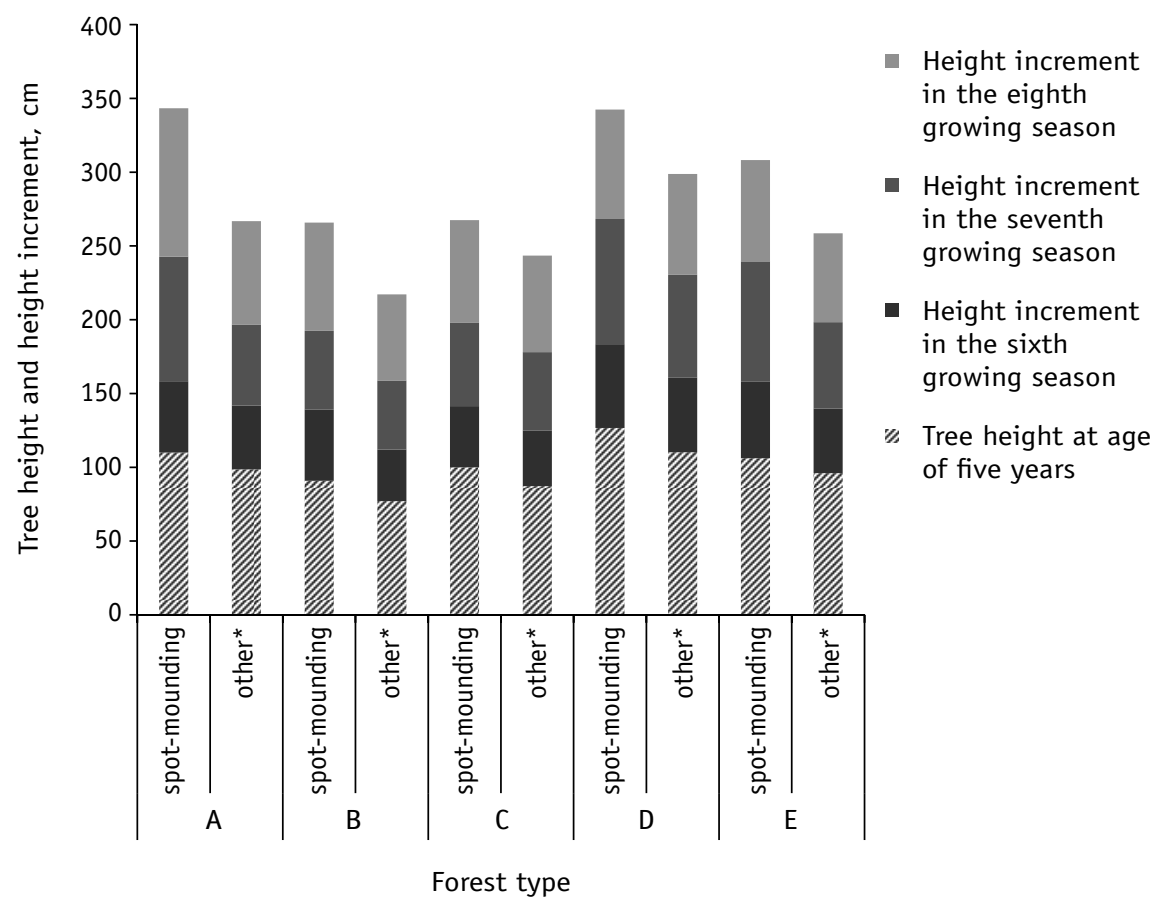

Figure 2. The total height and the height increment during last 3 growing seasons of the one hundred highest trees per ha- ${ }^{-1}$ at the age of 8 years.

* other: disc trenching in Myrtillosa (A), Hylocomiosa (B), Myrtillosa turf. mel. (C), unprepared soil in Oxalidosa (D), Myrtilloso-polytrichosa (E).

third of trees in Oxalidosa forest type and as much as two thirds in Myrtilloso-polytrichosa forest type were lower than $1.5 \mathrm{~m}$. Similar influence of soil preparation method on tree height distribution in young Norway spruce stand was found also in Finland (Uotila et al., 2010).

Differences in mean height of the trees (Figure 3) were significant $(p<0.05)$ in most of the forest types - on mineral soil with normal moisture regime (Myrtillosa, Hylocomiosa, Oxalidosa) and on wet mineral soil (Myrtilloso-polytrichosa). Less pronounced ( $p$ $=0.09)$ differences were found on drained peat soil (Myrtillosa turf. mel.), presumably due to impact of frost heave. Frost heave primarily affects areas on drained peat soils in Latvia (Mangalis, 2004). Study in central Finland found that it has been present mainly on areas with ditch mounded and inverted soil (Heiskanen et al., 2013).
Similar to our results, superior height growth of trees planted on mounds had been found also in numerous studies in Sweden and Finland (Saarinen, 2007; Lehtosalo et al., 2010; Uotila et al., 2010; Hallsby \& Örlander, 2013). Even so the reported (Örlander et al., 1990, 1998) differences in tree height between the soil preparation methods were smaller than those found in our study, presumably due to slower growth in more northern climatic conditions. Positive effect of spot-mounding might be a results of improved availability of nitrogen (faster mineralization) at the second and third growing season (Smolander \& Heiskanen, 2007; Nieminen et al., 2012) thus increasing the biomass and root growth of seedlings (Nordborg et al., 2003). In this respect both soil treatments with humus removal as well as planting in un-prepared soil yielded the worst results (Nordborg et al., 2003). These 


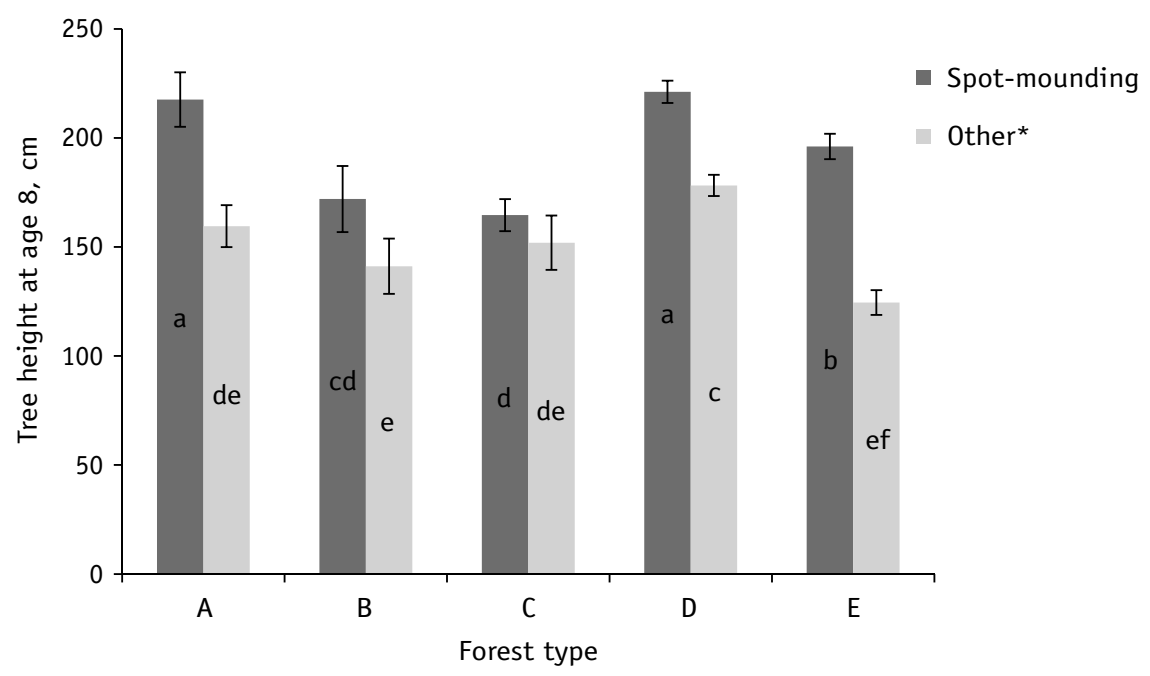

Figure 3. Tree height ( \pm confidence interval) in relation to soil preparation and forest type at the age of 8 years.

* other: disc trenching in Myrtillosa (A), Hylocomiosa (B), Myrtillosa turf. mel. (C), unprepared soil in Oxalidosa (D), Myrtilloso-polytrichosa (E). Arithmetic means denoted by the same letter show non-significant differences $(p>0.05)$.

findings are in line with our results where largest height differences were found between spruces growing on mounds and on unprepared soil (Figure 3). Lack of soil scarification leads to much more frequent pine weevil damages even if the plants are treated by insecticide in the nursery (Heiskanen et al., 2013). For example, study in Finland had found $76 \%$ of Norway spruce seedlings gnawed in unscarified spots during first growing season in field in contrast to only $1 \%$ gnawed on mounded spots (Heiskanen \& Viiri, 2005). Seedlings damaged by pine weevil were less vigour and had smaller height increment (Heiskanen \& Viiri, 2005; Heiskanen et al., 2013). Since our trials were established in fresh coniferous clearcuts, usually most affected by pine weevil, reduction of impact of this insect might be an important factor causing the observed differences in tree height distribution (Figure 1).

Mounding had produced better establishment and initial growth of Norway spruce plantations than patching or disc trenching due to combination of reduced seedling damage, improved thermal conditions and improved availability of nutrients (Kankaanhuhta et al., 2009; Heiskanen et al., 2016). Improved vigour in first years may have led to larger height increment of trees later on, as demonstrated by our results (Figure 2). Height increment of dominating trees of the last three growing seasons was larger in spot-mounded sites in comparison to disc-trenched ones. It showed significant differences in Myrtillosa and Hylocomiosa forest types during the eighth growing season, and in Myrtillosa type during the seventh growing season; however no significant differences were found during the sixth growing season. Height increment of the eighth and seventh year in areas with spot-mounding was higher also than in areas without soil preparation, but in the sixth growing season significant differences were found only in Myrtilloso-polytrichosa forest type $(p<0.05)$. Inter-annual differences in the results might be caused by variation of meteorological conditions affecting height 


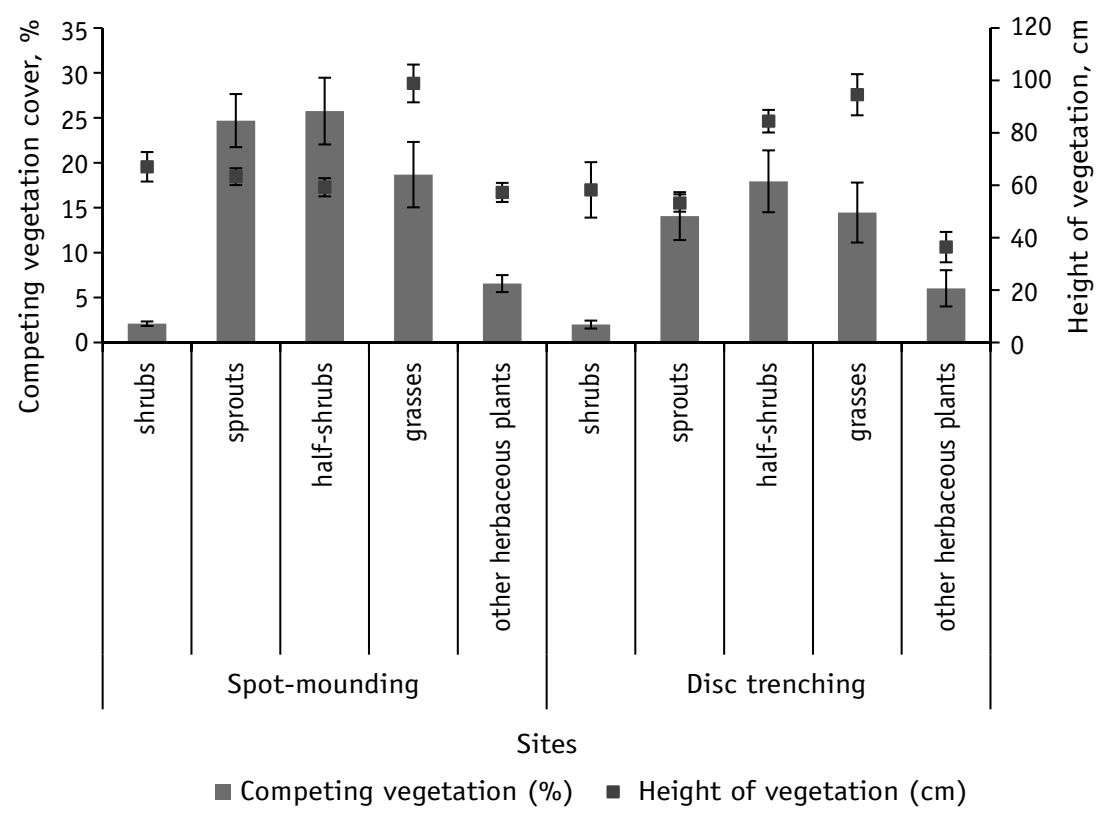

Figure 4. The projective cover ( \pm confidence interval) and height of competing vegetation ( \pm confidence interval) before tending in Myrtillosa turf. mel. forest type.

increment. Overall our results are in line with findings in Finland, demonstrating that mean height increment of spruces planted on mounds was slightly higher than for those planted in furrows ( $23.7 \pm 17.4$ and $20.6 \pm 13.6 \mathrm{~cm}$, respectively) leading to significant differences in height of trees at the end of $9^{\text {th }}$ growing season (Saksa et al., 2005).

\section{Tending in relation to soil preparation method}

Our results showed no differences in the abundance of ground vegetation on sites with spot mounding and disc trenching, if adjusted for the area of un-prepared soil. However, the actual mean projective cover of ground vegetation before the tending was significantly higher in spot-mounded sites in comparison to disc-trenched sites: 78 and $54 \%$, respectively.

Earlier studies in similar climatic conditions had found, that soil preparation method determines the shading of seedlings and thus the need for tending; the least shaded were seedlings planted on wide $(100 \mathrm{~cm})$ furrows and $30 \mathrm{~cm}$ high mounds (Suchockas et al., 2014). So both of the soil preparation methods analysed in our study can yield similar results in relation to vegetation competition. Soil preparation increases the ground vegetation species richness (Balandier et al., 2006), but not necessarily its impact to seedlings. Impact of ground vegetation is related to its vicinity to the seedling and delayed by soil preparation depth and width (Suchockas et al., 2014).

The sprouts, half-shrubs and grasses were the most abundant (85-89\%) type of competing vegetation in both spot-mounded and disc-trenched sites. The proportion of these vegetation groups was similar within sites with different soil preparation methods (Figure 4).

The mean weighted (the projective cover used as weights) height of vegetation was similar $(p>0.05)$ for sites with both types 


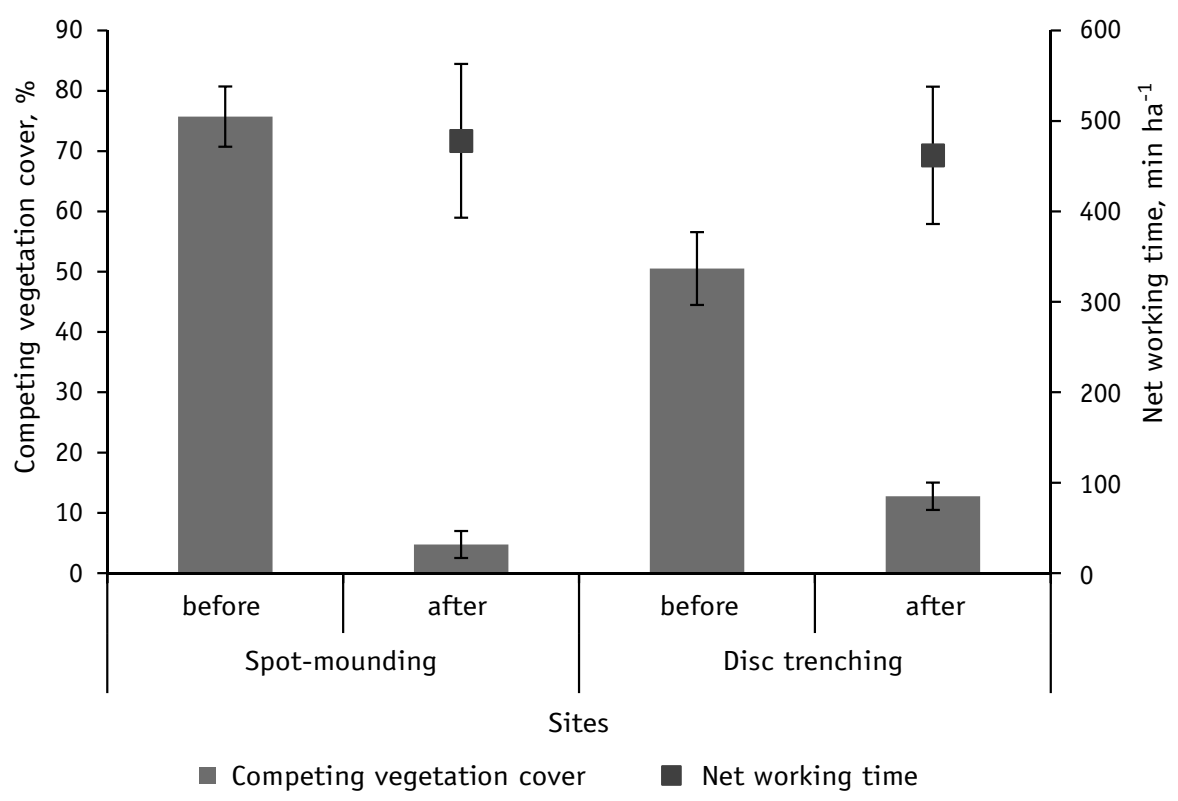

Figure 5. The competing vegetation cover ( \pm confidence interval) before and after tending, and net working time ( \pm confidence interval) in spot-mounded and disc-trenched sites.

of soil preparation. The height of grasses significantly exceeded that of other vegetation groups in spot-mounded sites. In disc-trenched sites, grasses and half-shrubs (mostly raspberries) were significantly higher than other vegetation groups. Similarly, grasses were the dominant ground vegetation type in second and third year after the clearcut in forest types on fertile soil also in Lithuania. Height of weeds were similar on ploughed berms and mounds (Suchockas et al., 2014). Grasses had been noted as most significant competitors, capable to reduce height-growth of seedlings, primarily due to fast root growth and consequently intensive water uptake by graminoids (Coll et al., 2003). In order to reduce this impact, need for tending was similar in both disctrenched and spot-mounded sites.

The projective covers of vegetation after tending was significantly lower in spot-mounded (5\%) in comparison to disctrenched (13\%) sites (Figure 5) and the mean height of it did not differ significantly $(p>$ $0.05)$. Statistically significant impact of replication on vegetation cover was not detected.

The networking time, as well as its proportion from total working time was similar $(p>0.05)$ for sites with different soil preparation: $478 \mathrm{~min} / \mathrm{ha}^{-1}(67 \pm 9.7 \%)$ and $462 \mathrm{~min} / \mathrm{ha}^{-1}(68 \pm 8.3 \%)$ in spot-mounded and disc-trenched sites, respectively.

\section{Conclusions}

Soil preparation method had significant effect on height of Norway spruce trees at the age of 8 years: planting on mounds resulted both in higher mean height as well as larger proportion of highest trees in comparison to planting on furrows or in unprepared soil. The difference between height increment of dominant (the highest 100 trees ha-1) trees in spot-mounded and disc-trenched sites increased gradually along with the age of 
the trees: from the average of $7 \mathrm{~cm}(14 \%)$ during the sixth growing season to $17 \mathrm{~cm}$ $(20 \%)$ during the eighth growing season. Tending in site prepared by spot mounding was as effective as in site prepared by disc trenching, reducing the vegetation cover to a negligible 5 and $13 \%$, respectively. Also the speed of the operation was unaffected by soil preparation method.

Overall the results suggest a great potential of spot mounding to improve the early growth of planted Norway spruce stands.

Acknowledgements. Study was carried out in European Social Fund project No. 2013/0022/1DP/1.1.1.2.0/13/APIA/ VIAA/052. Help of Agris Pobiarzens, Janis Liepins and Kaspars Liepins in different stages of the development of experimental sites is acknowledged.

\section{References}

Balandier, P., Collet, C., Miller, J.H., Reynolds, P.E., Zedaker, S.M. 2006. Designing forest vegetation management strategies based on the mechanisms and dynamics of crop tree competition by neighbouring vegetation. - Forestry, 79(1), 3-27.

Barbati, A., Corona, P., Marchetti, M. 2007. European forest types. Categories and types for sustainable forest management reporting and policy. EEA Technical report No 9. Office for Official Publications of the European Communities, Luxembourg. 111 pp.

Bušs, K. 1976. Forest classification in the Latvian SSR. (Latvijas PSR meža tipoloǵijas pamati). Riga, Silava. 24 pp. (In Latvian).

Coll, L., Balandier, P., Picon-Cochard, C., Prévesto, B., Curt, T. 2003. Competition for water between beech seedlings and surrounding vegetation in different light and vegetation composition conditions. - Annals of Forest Science, 60, 593-600.

Donis, J. 2014. Revised growth tables of main forest tree species in Latvia. (Latvijas mežsaimnieciski nozīmīgāko koku sugu pilnveidotās bonitāšu skalas). - Jansons, J. (ed.). Four Motives of Forest Science. (Četri mežzinātņu motīvi). Daugavpils, Saule, 13-36. (In Latvian).

Gradeckas, A., Malinauskas, A. 2005. Biological and ecological fundamental research and experience on establishment of forest plantations in Lithuania: monography. (Miško želdynų veisimo biologiniai ir ekologiniai veiksniai bei patirtis Lietuvoje: monografija). Kaunas, Lututè. 404 pp. (In Lithuanian).
Hallsby, G., Örlander, G. 2013. A comparison of longterm effects of scarification methods on the establishment of Norway spruce. - Forestry, 86, 91-98.

Heiskanen, J., Saksa, T., Hyvönen, J. 2016. Effects of mounding and soil clay content on postplanting success of Norway spruce. - Forest Ecology and Management, 378, 206-213.

Heiskanen, J., Saksa, T., Luoranen, J. 2013. Soil preparation method affects outplanting success of Norway spruce container seedlings on till soils susceptible to frost heave. - Silva Fennica, 47(1), article id 893. $17 \mathrm{p}$.

Heiskanen, J., Viiri, H. 2005. Effects of mounding on damage by the European pine weevil in planted Norway spruce seedlings. - Northern Journal of Applied Forestry, 22, 154-161.

ICP Forest. 2011. Assessment of Ground Vegetation. [WWW document]. - URL http:/ / www.icp-forests.org/pdf/FINAL_GV.pdf [Accessed 7 September 2015].

Jansons, Ā., Donis, J., Danusevičius, D., Baumanis, I. 2015. Differential analysis for next breeding cycle for Norway spruce in Latvia. - Baltic Forestry, 21(2), 285-297.

Kankaanhuhta, V., Saksa, T., Smolander, H. 2009. Variation in the results of Norway spruce planting and Scots pine direct seeding in privately-owned forests in southern Finland. - Silva Fennica, 43(1), 51-70.

Langvall, O., Nilsson, U., Örlander, G. 2001. Frost damage to planted Norway spruce seedlings - influence of site preparation and seedling type. - Forest Ecology and Management, 141, 223-235.

Lehtosalo, M., Mäkelä, A., Valkonen, S. 2010. Regeneration and tree growth dynamics of Picea abies, Betula pendula and Betula pubescens in regeneration areas treated with spot mounding in southern Finland. - Scandinavian Journal of Forest Research, 25, 213-223.

Liepiņš, K., Lazdiņa, D., Lazdiņš, A. 2011. Productivity and cost-effectiveness of the M-Planter tree planting machine in Latvian conditions. - Baltic Forestry, 17, 308-313.

Mangalis, I. 2004. Forest regeneration and afforestation. (Meža atjaunošana un ieaudzēšana). Riga, Et Cetera. 453 pp. (In Latvian).

Nieminen, J.K., Räisänen, M., Haimi, J. 2012. Spot mounding and granulated wood ash increase inorganic $\mathrm{N}$ availability and alter key components of the soil food web in clear-cut Norway spruce forests. - Forest Ecology and Management, 263, 24-30.

Nordborg, F., Nilsson, U., Örlander, G. 2003. Effects of different soil treatments on growth and net nitrogen uptake of newly planted Picea abies (L.) Karst. seedlings. - Forest Ecology and Management, 180, 571-582.

Örlander, G., Gemmel, P., Hunt, J. 1990. Site preparation: A Swedish overview. Canadian Forest Service Publications, FRDA Report 105. $61 \mathrm{pp}$.

Örlander, G., Hallsby, G., Gemmel, P., Wilhelmsson, C. 1998. Inverting improves establishment of 
Pinus contorta and Picea abies - 10-year results from a site preparation trial in Northern Sweden. - Scandinavian Journal of Forest Research, 13, 160-168.

Rantala, J., Saarinen, V.-M., Hallongren, H. 2010. Quality, productivity and costs of spot mounding after slash and stump removal. - Scandinavian Journal of Forest Research, 25, 507-514.

Report of State Forest Service, 2015. [WWW document]. - URL http://www.vmd.gov.lv/valstsmeza-dienests/statiskas-lapas/publikacijas-unstatistika?nid=1717\#jump [Accessed 29 September 2016].

Saarinen, V.-M. 2007. Productivity, quality of work and silvicultural result of mechanized planting. - NSFP Nordic Nursery Conference, Siilinjärvi (Finland), 5-6 September 2007. 13 pp.

Saksa, T, Heiskanen, J., Miina, J., Tuomola, J., Kolström, T. 2005. Multilevel modelling of height growth in young Norway spruce plantations in southern Finland. - Silva Fennica, 39, 143-153.

Saksa, T. 2008. The main keystones for improving the outcome of spruce planting. - A 40-year-anniversary research seminarium, Suonenjoki (Finland), 26 August 2008. 16 pp.
Sarma, P. 1959. Phytocoenoses dynamics of the Latvian SSR. (Динамика лесных фитоценозов в Латвийской ССР). Riga. 28 pp. (In Russian).

Schlyter, P., Stjernquist, I., Bärring, L., Jönsson, A.M., Nilsson, C. 2006. Assessment of the impacts of climate change and weather extremes on boreal forests in northern Europe, focusing on Norway spruce. - Climate Research, 31, 75-84.

Smolander, A., Heiskanen, J. 2007. Soil N and C transformations in two forest clear-cuts during three years after mounding and inverting. - Canadian Journal of Soil Science, 87, 251-258.

Suchockas, V., Malinauskas, A., Urbaitis, G., Pliūra, A. 2014. The influence of soil preparation on the development of ground vegetation in forest plantations on arable farmland and forest clear-cut areas. - Zemdirbyste-Agriculture, 101(4), 395-402.

Uotila, K., Rantala, J., Saksa, T., Harstela, P. 2010. Effect of soil preparation method on economic result of Norway spruce regeneration chain. - Silva Fennica, 44, 511-524.

Wallertz, K. 2009. Pine weevil feeding in Scots pine and Norway spruce regenerations. PhD Thesis, Alnarp, Swedish University of Agricultural Sciences, Acta Universitatis Agriculturae Sueciae. 46 pp. 